\title{
Analysis of proteins that interact with nucleocapsid protein of SARS-CoV using 15-mer phage-displayed library
}

\author{
LIU ZhengXue ${ }^{1,2 * \dagger}$, WANG ZhanHui ${ }^{1 *}$, LIU YingLe ${ }^{1}$, DONG Wei ${ }^{1}$ \& QI YiPeng ${ }^{1}$ \\ ${ }^{1}$ State Key Laboratory of Virology, College of Life Science, Wuhan University, Wuhan 430072, China; \\ ${ }^{2}$ Biology Department, Chongqing Three Gorges University, Chongqing 404000, China
}

Analysis of proteins that interact with $\mathrm{N}$ protein of SARS-CoV using 15-mer phage-displayed library will help to explore the virus pathogenesis and to develop new drugs and vaccines against SARS. In this study, we cloned, expressed and purified $\mathrm{N}$ protein of SARS-CoV. This $46-\mathrm{kD} \mathrm{N}$ protein was verified by SDS-PAGE and Western-blot. Then, the peptides binding-specific to $\mathbf{N}$ protein were identified using 15-mer phage-displayed library. Surprisingly, all of the 89 clones from monoclonal ELISA were positive $(S / N>2.1)$ and the result was further confirmed experimentally once again. Six $N$ protein-binding peptides, designated separately as SNA1, SNA2, SNA4, SNA5, SNA9 and SNG11, were selected for sequencing. Sequence analysis suggested that SNA5 shared approximatively $100 \%$ sequence identity to SNA4, SNA2, SNA9 and SNA1. In addition, the binding specificity of the 15-mer peptides with the SARS-CoV N protein was further demonstrated by blocking ELISA using the synthetical 15-mer peptide according to the deduced amino acid sequence of SNA5. Also, the deduced amino sequence of SNA5 was compared with proteins in translated database using the tblastx program, and the results showed that the proteins with the highest homology were Ubiquinol-cytochrome $c$ reductase iron-sulfur subunits (UCRI or UQCR), otherwise known as the Rieske iron-sulfur proteins (RISP). Notablely, in the [2Fe-2S] redox centre of UCRI, there were 6 residues [GGW(Y)F(Y)CP] compatible to the residues (position $2 \rightarrow 7$, GGWFCP7) of the NH2-terminal of the 15-mer peptide, which indicated higher binding specificity between the $\mathrm{N}$ protein of SARS-CoV and the redox centre of UCRI to some extent. Here, the possible molecular mechanisms of SARS-CoV N protein in the pathogenesis of SARS are discussed.

SARS-CoV, nucleocapsid protein, UCRI, phage display, blocking ELISA, 15-mer peptide library, apoptosis, pathogenesis

Severe acute respiratory syndrome (SARS) is an infectious disease and its causative agent has been identified as a novel human coronavirus, designated as SARSassociated coronavirus (SARS-CoV) ${ }^{[1-4]}$. It first outbroke in Guangdong Province, China at the end of 2002, and then it dramatically spread to more than 30 countries and regions, causing more than 800 deaths before being contained in $2003^{[5,6]}$. SARS-CoV is an enveloped, positive single stranded RNA virus with a genome of approximately $30000 \mathrm{nt}$ that encodes several non-structural proteins and 4 structural proteins ${ }^{[7,8]}$ : S gene, coding for the spike (S) protein; E gene, coding for the envelope (E) protein; $\mathrm{M}$ gene, coding for the membrane (M) protein and $\mathrm{N}$ gene, coding for nucleocapsid $(\mathrm{N})$ protein.

The direction of SARS research has now moved from identifying the virus and sequencing its genome to analyzing the viral proteins and their roles in virus replication and pathogenesis with the aim to develop new drugs and vaccines against $\mathrm{SARS}^{[9,10]}$. Although steroids and

\footnotetext{
Received January 31, 2007; accepted April 16, 2007

doi: 10.1007/s11434-007-0303-0

*Contributed equally to this work

†Corresponding author (email: zxliu99@yahoo.com.cn)

Supported by the Science and Technology Project of Chongqing Municipal Education Commission, China (Grant No. KJ071109) and the Key Project of the Ministry of Science and Technology of China (Grant No. 2003CB514120)
} 
antiviral drugs were tried clinically, no treatment has clearly been confirmed to be effective ${ }^{[11-15]}$ for lack of knowledge about the molecular mechanism(s) underlying the pathogenesis of SARS ${ }^{[12,13,15,16]}$.

The SARS-CoV N protein, encoded with $1259 \mathrm{nt}$ at the $3^{\prime}$ end of the viral genome, has an estimated molecular mass of $46 \mathrm{kD}$. The protein has been predicted to interact with the viral RNA, and both constitute the viral nucleocapsid, but no studies have hitherto been reported on the proteins interacting with $\mathrm{N}$ protein of SARS-CoV. We therefore tried to analyze proteins that interact with $\mathrm{N}$ protein of SARS-CoV to explore the virus pathogenesis aiming to develop new drugs and vaccines against SARS by using 15 -mer phage-displayed technology and the gapped tblastx program.

\section{Materials and methods}

\subsection{Viruses, library, bacteria and reagents}

The SARS-CoV used in this experiment was isolated and provided by the Nanfang Hospital, China. We have reported the entire genome (GenBank Accession No. AY390556) elsewhere. The phage display library used was 15-mer peptide library, which was constructed in the fUSE 5 vector and displayed a foreign random 15-mer peptide on all 5 copies of capsid protein III. The bacterial strain was K91. Both the library and bacterial strain were donated by MRC Geneservice. NBT/BCIP (Sigma), mouse anti-His monoclonal antibody (Sigma) and horseradish peroxidase-conjugated goat anti-mouse IgG (Sigma) were all purchased from distributors. Other commonly used reagents are all of analytic purification grade and made in China.

\subsection{SARS-CoV RNA extraction}

Lung tissue sample was collected from the first autopsy woman who was confirmed a victim of SARS-CoV infection. Viral RNA was isolated from tissue sample by using Trizol reagent (Invitrogen) according to the manufacturer's instructions. $100 \mathrm{mg}$ tissue was homogenized in $1 \mathrm{~mL}$ Trizol reagent. After chloroform extraction and isopropyl alcohol precipitation, the RNA pellet was dissolved into $30 \mu \mathrm{L}$ distilled water. cDNA synthesis was performed using Thermoscript (Invitrogen) with oligo (dT) and random hexamers primers according to the manufacturer's instructions.

\subsection{N gene amplification}

One $\mathrm{mL}$ cDNA was used as a template for SARS $\mathrm{N}$ gene amplification with two $\mathrm{N}$ gene specific primers pNS (5'-CTCGGATCCATGTCTGATAATGGACCCC-3', the upstream primer) and pNA (5'-CTGGCGGCCGCTGCCTGAGTTGAATCAGCAG-3', the downstream primer), in which BamH I and Not I restriction enzyme cleavage sites were designed, respectively (the restriction sites were underlined). The PCR was performed in a 96-well cycler (GeneAmp PCR System 9700; Applied Biosystems, Foster City, Calif.) and in a $50 \mu \mathrm{L}$ reaction volume containing 2 U LA Taq (TaKaRa Biotechnology Co. Ltd., Dalian, China). The cycling conditions were initial denaturation at $94^{\circ} \mathrm{C}$ for $1 \mathrm{~min}$, followed by 35 cycles of denaturation at $94^{\circ} \mathrm{C}$ for $25 \mathrm{~s}$, annealing at $56^{\circ} \mathrm{C}$ for 30 $\mathrm{s}$ and extension at $72^{\circ} \mathrm{C}$ for $2 \mathrm{~min} .6 \mathrm{~mL}$ amplicons were analyzed by electrophoresis on $1.5 \%$ agarose gel, stained with ethidium bromide, and observed under UV light.

\subsection{Plasmid construction}

The PCR products were double digested with BamH I and Not I restriction enzyme, purified with QIAquick gel extraction kit (QIAGEN Inc., Hilden, Germany), and then cloned into pET-28(a) expression plasmid from Novagen Inc. (USA) using standard procedures. The correct insert size was confirmed using PCR and restriction enzyme BamH I and Not I (TaKaRa Biotechnology Co. Ltd., Dalian, China). DNA sequencing analysis of the correct recombinant was performed with an automated DNA sequencer ABI 377 (Applied Biosystems).

\subsection{Expression and purification of nucleocapsid protein}

Expression and purification of nucleocapsid protein were carried out essentially in the same way as previously described ${ }^{[17]}$.

\subsection{Preparation of starved cells}

K91 cells were cultured by vigorously $(250 \mathrm{r} / \mathrm{min})$ shaking at $37^{\circ} \mathrm{C}$ in $20 \mathrm{~mL} \mathrm{LB}$ to mid log phase $\left(A_{600}\right.$ $0.4-0.6)$, incubated by gently $(50 \mathrm{r} / \mathrm{min})$ shaking at $37^{\circ} \mathrm{C}$ for additional $5 \mathrm{~min}$ to allow any sheared F-pili to regenerate, and centrifuged at room temperature, 2200 $\mathrm{r} / \mathrm{min}$ for $10 \mathrm{~min}$. After pouring and pipetting off all the supernatant, the cells were gently resuspended in $10 \mathrm{~mL}$ $20 \mathrm{mmol} / \mathrm{L} \mathrm{NaCl}$ and starved by shaking at $37^{\circ} \mathrm{C}, 110$ $\mathrm{r} / \mathrm{min}$ for $45 \mathrm{~min}$. The cells were centrifuged again and 
resuspended in $1 \mathrm{~mL}$ cold NAP buffer and stored in cells at $4{ }^{\circ} \mathrm{C}$. The starved cells could remain infectible for $\sim 5 \mathrm{~d}$ and the concentration of viable cells was $\sim 5 \times 10^{9} / \mathrm{mL}$.

\subsection{Affinity selection}

The affinity selection procedure was based on the biopanning methods as previously described ${ }^{[17]}$. The immunotubes were coated with purified $\mathrm{N}$ protein as described above overnight at $4^{\circ} \mathrm{C}$, followed by pouring away the supernatant and blocking the tube with a solution of $2 \%$ non-fat milk in Tris-buffered saline (MTBS) at room temperature for $2 \mathrm{~h}$. After removal of the blocking solution, the tube was washed three times with TBS. Then $50 \mu \mathrm{L}$ of the initial library solution $\left(1.2 \times 10^{14}\right.$ phages in $2 \%$ MTBS) (or $100 \mu \mathrm{L}$ of an amplified eluate from the previous round of affinity selection) was added. After standing at room temperature for $1 \mathrm{~h}$, the unspecific binding phages were washed away with TBS containing $0.1 \%$ Tween for 10 times (20 times in the other round). The remaining phages were eluted with $1 \mathrm{~mL}$ of $0.1 \mathrm{~mol} / \mathrm{L}$ Glycine- $\mathrm{HCl}$ buffer ( $\mathrm{pH} 2.2$ ), and the elution fraction was subsequently neutralized with $200 \mu \mathrm{L}$ of 1 $\mathrm{mol} / \mathrm{L}$ Tris-HCl ( $\mathrm{pH}$ 9.1). Three rounds of affinity selections were performed. The eluate was titered and amplified. The amplified eluates were subjected to two further rounds of enrichment.

\subsection{Quantifying yield and amplifying eluates}

The $500 \mu \mathrm{L}$ of starved K91 cells as above was infected with $1 \mathrm{~mL}$ of the neutralized phages at room temperature for 30 min without shaking ( $100 \mu \mathrm{L}$ of starved K91 cells was infected with $100 \mu \mathrm{L}$ of neutralized phages in the other round at the same conditions), added into $20 \mathrm{~mL}$ of LB containing $1 \mu \mathrm{L}$ of $5 \mathrm{mg} / \mathrm{mL}$ tetracycline (TC) at a final concentration of $0.2 \mu \mathrm{g} / \mathrm{mL}$, cultured at $37^{\circ} \mathrm{C}, 150$ $\mathrm{r} / \mathrm{min}$ for $40-60 \mathrm{~min}$. Then a small proportion of infected K91 was titrated in 4-fold dilutions, starting with $1: 10$, to determine the phage titer. $40-\mu \mathrm{L}$ portions of appropriate serial dilutions of the culture (diluent $=\mathrm{LB}$ ) were spread on LB plates containing $40 \mu \mathrm{g} / \mathrm{mL}$ TC to quantify the output of the affinity selection by calculating clones on the LB plates. The rest of infected K91 with $80 \mu \mathrm{L}$ of $5 \mathrm{mg} / \mathrm{mL}$ TC added (at a final concentration of $20 \mu \mathrm{g} / \mathrm{mL}$ ) was incubated at $37^{\circ} \mathrm{C}, 250 \mathrm{r} / \mathrm{min}$ overnight, and centrifuged at $8000 \mathrm{r} / \mathrm{min}$ for $10 \mathrm{~min}$ followed by centrifuging at $5000 \mathrm{r} / \mathrm{min}$ for $10 \mathrm{~min}$. Subsequently, $3 \mathrm{~mL}$ of $\mathrm{PEG} / \mathrm{NaCl}$ was added, mixed and re- acted without shaking at $4^{\circ} \mathrm{C}$ overnight. After centrifuging at $10000 \mathrm{r} / \mathrm{min}$ for $10 \mathrm{~min}$, the sediment was suspended in $1 \mathrm{~mL}$ of TBS and centrifuged at 12000 $\mathrm{r} / \mathrm{min}$ for $1 \mathrm{~min}$. $150 \mu \mathrm{L}$ of $\mathrm{PEG} / \mathrm{NaCl}$ was added in the supernatant, mixed and reacted without shaking at $4{ }^{\circ} \mathrm{C}$ for $4 \mathrm{~min}$. After centrifuging at $12000 \mathrm{r} / \mathrm{min}$ for $5 \mathrm{~min}$, the sediment was suspended in $200 \mu \mathrm{L}$ of TBS and centrifuged at $12000 \mathrm{r} / \mathrm{min}$ for $1 \mathrm{~min}$. The supernatant was transferred into an Eppendorf tube and stored at $4^{\circ} \mathrm{C}$ as input for further rounds of affinity selection.

\subsection{Monoclonal phage ELISA}

In the last selection round, individual clones were randomly picked out from the LB plate to different wells (150 $\mu \mathrm{L}$ of LB with $20 \mu \mathrm{g} / \mathrm{mL}$ TC was added in advance) of an ELISA plate. After culturing at $37^{\circ} \mathrm{C}, 150 \mathrm{r} / \mathrm{min}$ overnight, $50 \mu \mathrm{L}$ of culture from each well was transferred to the corresponding well of a second ELISA plate $(150 \mu \mathrm{L}$ of LB with $20 \mu \mathrm{g} / \mathrm{mL}$ TC was added in advance). The original ELISA plate was stored at $4^{\circ} \mathrm{C}$ temporarily. The transferred plate was shaken at $37^{\circ} \mathrm{C}$, $150 \mathrm{r} / \mathrm{min}$ overnight and centrifuged at $1800 \mathrm{~g}$ for 10 min. $50 \mu \mathrm{L}$ of the phage supernatant from each well was added in the corresponding well of ELISA plate coated with purified $\mathrm{N}$ proteins (the plate was blocked and washed in advance as described above). After incubation for $1 \mathrm{~h}$ at room temperature, the plate was washed three times with TBS containing $0.5 \%$ Tween and TBS, respectively. $100 \mu \mathrm{L}$ of HRP-anti-M13 (1:2500 dilution in $2 \%$ MPBS) was added to each well. After incubation for an additional $1 \mathrm{~h}$ at $37^{\circ} \mathrm{C}$, the wells were washed again, and $100 \mu \mathrm{L}$ of fresh substrate solution $(100 \mu \mathrm{g} / \mathrm{mL}$ TMB in $100 \mathrm{mmol} / \mathrm{L}$ sodium acetate, $\mathrm{pH} 6.0,30 \%$ hydrogen peroxide) was added to each well. Enzyme reaction was terminated by adding $50 \mu \mathrm{L}$ of $2 \mathrm{~N} \mathrm{H}_{2} \mathrm{SO}_{4}$. Absorbance was measured at $450 \mathrm{~nm}$ and evaluated by $\mathrm{S} / \mathrm{N}$ (sample/negative).

\subsection{The specific procedure for blocking ELISA}

The brief outline of the blocking ELISA used was as follows: ELISA plate coated with purified $\mathrm{N}$ protein $(3.5$ $\mu \mathrm{g} / \mathrm{mL} ; 1: 25,1: 50,1: 100,1: 200,1: 400,1: 800$ dilution in $2 \% \mathrm{MPBS}$ ); $50 \mu \mathrm{L}$ of the synthetic 15 -mer peptide (synthesized with the sequence corresponding to that of the SNA5 phage clone peptide insert provided by Wuhan Shanying Biotechnology, Co. Ltd., China; 1:100, $1: 200,1: 400,1: 800$ dilution in 2\% MPBS), $30 \mathrm{~min}$, 
$37^{\circ} \mathrm{C}$, plus $50 \mu \mathrm{L}$ of the SNA5 phage supernatant $\left(5 \times 10^{9}\right.$ $\mathrm{cfu} / \mathrm{mL}), 30 \mathrm{~min}, 37^{\circ} \mathrm{C}$; wash $3 \times ; 100 \mu \mathrm{L}$ of HRP-antiM13 (1:2500 dilution in $2 \%$ MPBS), $60 \mathrm{~min}, 37^{\circ} \mathrm{C}$. The rest of the assay was done exactly in the same way as described for monoclonal phage ELISA.

The results were interpreted by calculating the percent inhibition (PI) using the following formula ${ }^{[18]}$ : PI $(\%$ inh $)=\left(1-\left(\left(\right.\right.\right.$ test $A_{450}-$ negative control $\left.A_{450}\right) \div($ positive control $A_{450}-$ negative control $\left.\left.\left.A_{450}\right)\right)\right) \times 100$.

\subsection{DNA sequencing}

Sequencing of the phage clones was undertaken using primer 5'-TGAATTTTCTGTATGAGG-3'. The primer for the fUSE vector clones is aligned with the sequences of our random peptide libraries.

\subsection{Sequence analysis}

The 15-mer peptides were identified by alignment with predicted amino acid sequences on translated database. Multiple amino acid alignments were performed using "Vector NTI 8.0" alignment program (Biosoft, InforMax, Inc., USA).

\section{Results}

\subsection{Expression and purification of a (His) $)_{6}-\mathrm{N}$ fusion protein}

The gene encoding $\mathrm{N}$ protein of SARS-CoV was amplified, cloned into pET-28(a) expression plasmid and $E$. coli BL21 (DE3) cells were used for expression of a (His) ${ }_{6}-\mathrm{N}$ fusion protein. The Western-blot results (Figure 1) showed clearly that the cellular homogenates from $E$. coli BL21 (DE3) cells after 1, 3, and $5 \mathrm{~h}$ induced by IPTG gave the positive signals.

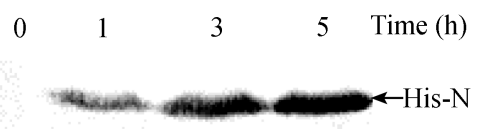

Figure $1 \mathrm{~N}$ protein expression by Western-blot analysis. Analysis of reactivity of the total cell lysates with polyhistidine antibody. Cellular homogenates, concentrated cellular medium, from E. coli B1 21 (DE3) cells after $0,1,3$, and $5 \mathrm{~h}$ induction by IPTG. Induction after 1,3 , and $5 \mathrm{~h}$ gives a positive signal.

The $(\text { His })_{6}-\mathrm{N}$ fusion protein was purified with the immobilized nickel affinity resin (His-Bind resin) purchased from Novagen Inc. (USA). The purification results of $\mathrm{N}$ proteins are shown in Figure 2. The purified $\mathrm{N}$ proteins migrated as a single protein band on SDS-AGE (Figure 2A). It had an estimated molecular mass of highly pure $46 \mathrm{kD}$. As shown in Figure 2B, Western-blot analysis of the purified $\mathrm{N}$ protein also verified the result of SDS-PAGE. The production yield of purified N protein was around $3.5 \mathrm{mg} / \mathrm{L}$ of production culture valued by absorbance at $280 \mathrm{~nm}$ of the purity solution.

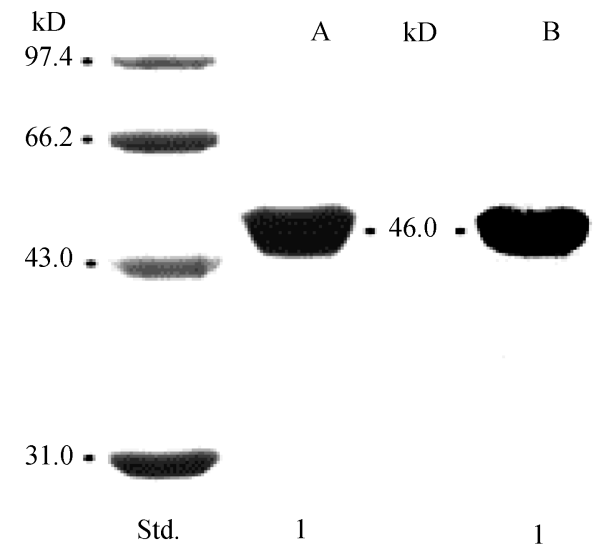

Figure 2 SDS-PAGE and Western blot of the purified recombinant $\mathrm{N}$ proteins. Std, The left-hand lane contains the molecular weight markers, with masses indicated to the left of the figure. A, The central lane shows SDS-PAGE of the purified recombinant $\mathrm{N}$ proteins; $\mathrm{B}$, the right-land lane depicts Western blot of the purified recombinant $\mathrm{N}$ proteins.

\subsection{Selection of $\mathrm{N}$ protein-specific binding clones from 15-mer phage display library}

The 15-mer peptide phage library donated by MRC Geneservice was used for selection of $\mathrm{N}$ protein-specific polypeptides. Three rounds of panning were done in the immunotubes coated with purified $\mathrm{N}$ protein. After each round of panning, the titer of the eluted phages was measured as colony-forming units (cfu) by the analytical titrating procedure to monitor the efficiency of the selection process as shown in Table 1. For the 1st and 2nd rounds, the titer of phages eluted was less than that of phages input from $5.7 \times 10^{11}$ to $1.39 \times 10^{5}$ (Yield, $\left(2.4 \times 10^{-5}\right) \%$ ) and from $1.39 \times 10^{4}$ to $2.5 \times 10^{3}$ (Yield, $17.9 \%)$. After the third round of panning, the titer of phages was from $2.5 \times 10^{2}$ to $1.27 \times 10^{5}$ with a yield (\%) of $5.1 \times 10^{4}$, which indicated that the saturation point had been reached.

Table 1 Selective enrichment of the binding-specific phages from the 15-mer library

\begin{tabular}{cccc}
\hline Lists & 1st round & 2nd round & 3rd round \\
\hline Phage input $(\mathrm{cfu} / \mathrm{mL})$ & $5.7 \times 10^{11}$ & $1.39 \times 10^{4}$ & $2.5 \times 10^{2}$ \\
Phage eluted $(\mathrm{cfu} / \mathrm{mL})$ & $1.39 \times 10^{5}$ & $2.5 \times 10^{3}$ & $1.27 \times 10^{5}$ \\
Yield $(\%)^{\mathrm{a})}$ & $2.4 \times 10^{-5}$ & 17.9 & $5.1 \times 10^{4}$ \\
\hline
\end{tabular}

a) Yield $(\%)=($ No. of phage eluted/No. of phage input $) \times 100 \%$.

\subsection{Specificity assessment of the 15-mer library}

After the final panning step, the $\mathrm{N}$ protein binding 
specificity of phage-displayed peptides was judged by ELISA with 89 randomly picked individual clones using uncoated ELISA plates and plates directly coated with purified N protein and BSA alone. Surprisingly, all the clones were positive ( $\mathrm{S} / \mathrm{N}>2.1)$ (Figure 3 ). Of them, four positive clones, i.e. SNA1 $\left(A_{450}, 0.130\right)$, SNA8 $\left(A_{450}\right.$, $0.086)$, SNF6 $\left(A_{450}, 0.362\right)$ and SNG8 $\left(A_{450}, 0.208\right)$, gave the weakest positive signals. These phenomena were further confirmed by a repeated experiment (see Figure 4, data not shown).

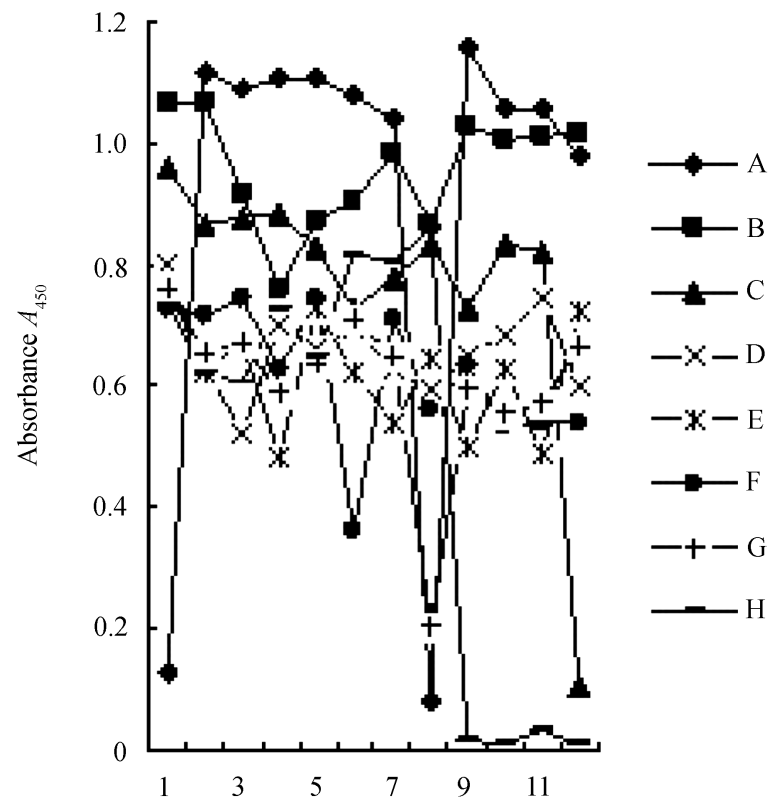

Figure 3 Reactivity of N protein-specific clones selected from the third round of panning given as absorbance in monoclonal phage ELISA (1st selection). The signs "A $-\mathrm{H}$ " and the numbers " $1-12$ " expresses wellcoordinates of the ELISA plate. H6, $\mathrm{H} 7$ and $\mathrm{H} 8$ represent positive controls (coated with purified N protein); H9, H10 and H11 express negative controls (coated with BSA); H12 indicates blank control (uncoated). Optical density was measured as $A_{450}$, the ELISA positive was defined as $\mathrm{S} / \mathrm{N}>2.1$. Notice that all of the 89 clones from monoclonal ELISA were positive, which was likely relative to high antigenicity and specificity of SARS-CoV N protein. Six positive clones we selected: SNA5, SNA4, SNA2, SNA1, SNA9 and SNG11 are corresponding to A5, A4, A2, A1, A9 and G11, respectively.

\subsection{Sequences analysis}

Six positive clones selected in monoclonal phage ELISA, namely SNA1, SNA2, SNA4, SNA5, SNA9 and SNG11, were sequenced by Shanghai Casarray and Gene (Shanghai, China). Of them, SNA2, SNA4 and SNA9 were selected from the first experiment and SNA1, SNA5 and SNG11 from the repeated one. The nucleotide sequences and deduced amino acid sequences are listed in Table 2 for comparison. It could be seen that SNA5 shared $100 \%$ sequence identity to SNA4 and SNA1, 95.6\% nucleotide (position 43 and $45, \mathrm{~T} \rightarrow \mathrm{G}$ )

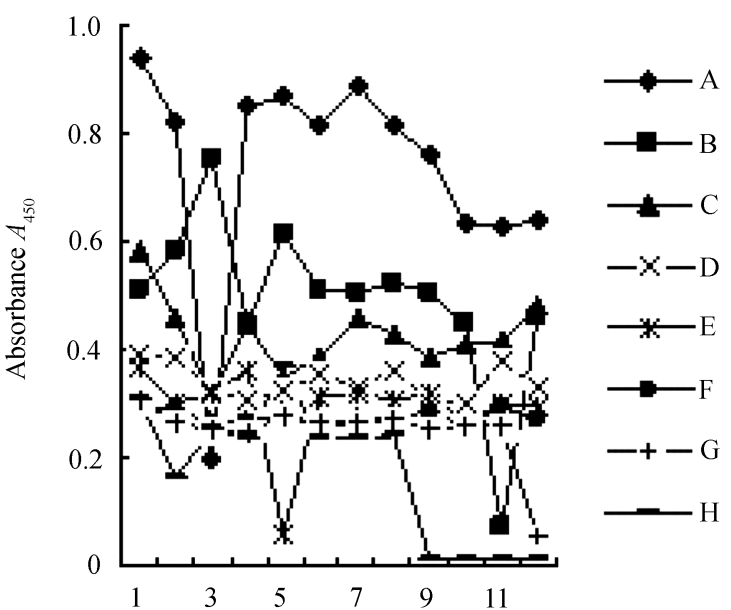

Figure 4 Reactivity of N protein-specific clones selected from the third round of panning given as absorbance in monoclonal phage ELISA (2nd selection). All the annotations are the same as in Figure 3.

and $93.3 \%$ amino acid (position $15, \mathrm{C} \rightarrow \mathrm{G}$ ) sequence identity to SNA2, 95.6\% nucleotide (position $17, \mathrm{G} \rightarrow \mathrm{T}$ and position $18, \mathrm{~T} \rightarrow \mathrm{G}$ ) and $93.3 \%$ amino acid (position $6, \mathrm{C} \rightarrow \mathrm{L}$ ) sequence identity to SNA9 and $100 \%$ sequence identity to SNG11 in a small region from nucleotides $1 \rightarrow 18$ (amino acids $1 \rightarrow 6$ ) as well. In addition, there were two nucleotide replacements (position 28, A $\rightarrow \mathrm{T}$; position $29, \mathrm{G} \rightarrow \mathrm{A}$ ) that a stop codon TAG (amber termination codon) to degenerate in the middle region of SNG11 with a lower $A_{450}$ of 0.261 than that of the other positive clones, which might indicate that the integrality of the 15-mer peptides played an important role in the specific binding to SARS-CoV N proteins.

\subsection{Blocking ELISA analysis}

To further investigate the binding specificity of the 15-mer peptides with the SARS-CoV N proteins, the 15-mer peptide (SNA5) was synthesized according to the deduced amino acid sequence of SNA5 and the blocking ELISA was performed. The results (Table 3) of blocking ELISA suggested that the bigger the concentration of the purified $\mathrm{N}$ protein, the bigger the percent inhibition (PI, \%inh) of the synthetic 15-mer peptide; in contrast, the bigger the dilution ratio of the synthetic 15-mer peptide, the smaller the required concentration of the purified $\mathrm{N}$ protein, indicating that the 15-mer peptides we obtained had a higher binding specificity of the SARS-CoV N protein.

\subsection{Analysis of proteins to interact with $\mathrm{N}$ protein of SARS-CoV}

SNA5 was chosen for further analysis. The deduced 
Table 2 Comparison of the nucleotide and amino acid sequences of six positive clones selected in monoclonal phage ELISA

\begin{tabular}{|c|c|c|c|}
\hline Sample & $A_{450}$ & Type $^{\text {a) }}$ & Sequence $^{\text {b) }}$ \\
\hline \multirow[t]{2}{*}{ SNA5 } & 0.968 & B & GGT GGT GGT TGG TTT TGT CCG ATT GTT AGG GGG CGG GTT TCT TGT \\
\hline & & A & $\begin{array}{lllllllllllllll}G & G & G & W & F & C & P & I & \text { V } & \text { R } & \text { G } & \text { R } & \text { V } & \text { S } & \text { C }\end{array}$ \\
\hline \multirow[t]{2}{*}{ SNA4 } & 1.108 & B & GGT GGT GGT TGG TTT TGT CCG ATT GTT AGG GGG CGG GTT TCT TGT \\
\hline & & A & $* \quad *$ \\
\hline \multirow{2}{*}{ SNA2 } & & B & GGT GGT GGT TGG TTT TGT CCG ATT GTT AGG GGG CGG GTT TCT GGG \\
\hline & 1.115 & A & $* \quad * \quad * \quad * \quad * \quad * \quad * \quad * \quad * \quad *$ \\
\hline \multirow{2}{*}{ SNA1 } & 0938 & B & GGT GGT GGT TGG TTT TGT CCG ATT GTT AGG GGG CGG GTT TCT GGG \\
\hline & 0.938 & A & $* \quad * \quad * \quad * \quad * \quad * \quad * \quad * \quad * \quad * \quad * \quad * \quad * \quad * \quad * \quad *$ \\
\hline \multirow{2}{*}{ SNA9 } & 155 & B & GGT GGT GGT TGG TTT TTG CCG ATT GTT AGG GGG CGG GTT TCT TGT \\
\hline & 1.134 & A & $* * * * * \quad * \quad * \quad * \quad * \quad * \quad * \quad * \quad * \quad * \quad \mathrm{C}$ \\
\hline \multirow{2}{*}{ SNG11 } & ○า & B & 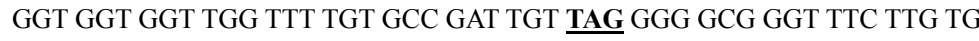 \\
\hline & 0.261 & A & $* * * \quad * \quad * \quad$ A $\quad$ D $\quad$ C amber termination codon \\
\hline
\end{tabular}

a) "B" and "A" are the abbreviations of "base" and "amino acid", respectively. b) The sign "*” expresses homology. TAG (amber termination condon) is underlined.

Table 3 The results of blocking ELISA ${ }^{\text {a) }}$

\begin{tabular}{ccccccc}
\hline $\begin{array}{c}\text { Dilution ratios of the synthetic } \\
15-\text { mer peptide }\end{array}$ & \multicolumn{5}{c}{ Dilution ratios of the purified N protein } \\
\cline { 2 - 7 } & $1: 25$ & $1: 50$ & $1: 100$ & $1: 200$ & $1: 400$ & $1: 800$ \\
\hline $1: 100$ & 82 & 72 & 59 & 46 & 34 & 23 \\
$1: 200$ & 85 & 77 & 69 & 58 & 38 & 19 \\
$1: 400$ & 84 & 82 & 74 & 63 & 42 & 26 \\
$1: 800$ & 85 & 89 & 80 & 71 & 47 & 17 \\
\hline
\end{tabular}

a) The blocking ELISA values are expressed as percent inhibition (IP, $\%$ inh) of the 15-mer peptide diluted $1: 100,1: 200,1: 400$ and $1: 800$, respectively.

amino acid sequence of SNA5 was compared with proteins in translated database (all GenBank+EMBL+ DBJ+DB sequences, but no EST, STS, GSS, environmental samples or phase 0,1 or 2 HTGS sequences) using the tblastx program. The proteins with the highest homology were Ubiquinol-cytochrome c reductase ironulfur subunits (UCRI or UQCR), otherwise known as the Rieske iron-sulfur proteins (RISP), from many biological species. The protein includes only four cysteines, which are assumed to bind the $2 \mathrm{Fe}-2 \mathrm{~S}$ cluster, located in a moderate hydrophobic region of this large domain. And cysteines 3 and 4 are unusually arranged as they are separated by only one praline ${ }^{[19]}$. The sequences of CRIs and the 15-mer peptides were compared in Figure 5. Surprisingly, the six residues (position $2 \rightarrow 7$, GGWFCP7) in the $\mathrm{NH}_{2}$-terminal of the 15 -mer peptides were just located in the $[2 \mathrm{Fe}-2 \mathrm{~S}]$ redox centres of UCRIs from Arabidopsis thaliana (gi|7543911|emb|CAB87151.1|, position $232 \rightarrow 237$ ), Solanum tuberosum (gi| 488848 $\mathrm{emb} \mid$ AA55894.1|, position $223 \rightarrow 238$ ), Nicotiana tabacum (gi|530053|gb|AAA20832.1|, position 226 $\rightarrow$ 231), Chlamydomonas reinhardtii (gi|27525857|emb| AC86460.2|, position $220 \rightarrow 225$ ), Neurospora crassa (gi|3002|emb|CAA26308.1|, position $189 \rightarrow 194$ ), Cryptococus neoformans var. neoformans JEC2 1
(gi|57227160|gb|AAW43619.1|, position 236 $\rightarrow 241$ ), Schizosaccharomyces pombe (gi|6320811|ref| P_010890.1|, position 174 $\rightarrow$ 179), Candida glabrata (gi|49526697|mb|CAG60324.1|, position $172 \rightarrow 177$ ), Aspergillus nidulans (gi|40745261|gb|EAA64417.1|, position $196 \rightarrow 201)$ and showed extensive sequence similarity to the corresponding region (position $2 \rightarrow 7$, GGYYCP7) of UCRIs from Apis mellifera (gi| 8096291|ref|XP_394657.1|, position 232 $\rightarrow$ 237), Drosophila pseudoobscura (gi|54645363|gb|EAL34103.1|, position $188 \rightarrow 193$ ), Danio rerio (gi|47155579|ref |P_998251.1|, position 231 $\rightarrow$ 236), Cebus paella (gi| 9939328|gb|AAR32718.1|, brown capuchin, position $160 \rightarrow 165$ ), Lung, smallcellcarcinoma (NCBI TaxID: 9606, position $232 \rightarrow 237$ ), Lymph, Burkittlymphoma (NCBI TaxID: 9606, position 232 $\rightarrow 237$ ), Brain, hypothalamus (NCBI TaxID: 9606, position $232 \rightarrow 237$ ), which indicated higher binding specificity between the $\mathrm{N}$ protein of SARS-CoV and the redox centre of UCRI to some extent. However, the reactivity of the SARS$\mathrm{oV} N$ protein with the redox centre of UCRI should be clarified by the protein-protein interaction experiments we are now performing on pull-down, co-immunoreipitation (co-IP), yeast two-hybrid and so on.

\section{Discussion}

Since the nucleocapsid $(\mathrm{N})$ proteins of known coronaviruses are relatively conserved and the $\mathrm{N}$ gene of the SARS-CoV contains no glycosylation $\operatorname{sites}^{[7,8]}$, we expressed the $\mathrm{N}$ proteins of SARS-CoV in E. coli. The results of SDS-PAGE and Western blot demonstrated that the recombinant $\mathrm{N}$ proteins had an estimated molecular mass of $46 \mathrm{kD}$. Then, the peptides bindingpecific to $\mathrm{N}$ protein were identified using 15 -mer 


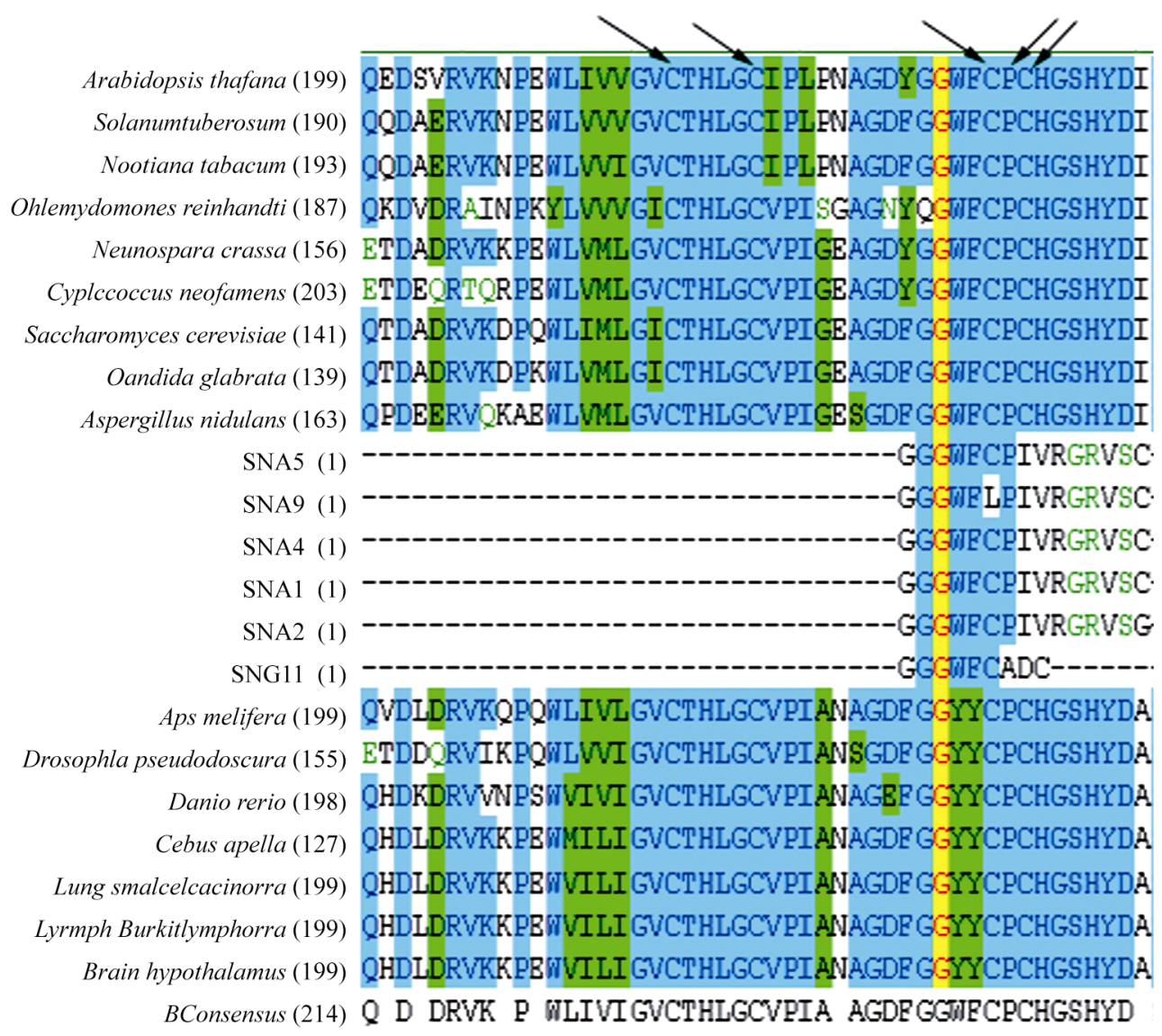

Figure 5 Homology analysis of the amino acid sequences of 6 positive clones selected in monoclonal phage ELISA and UCRIs from different biological species. Arrows represent the only four cysteines of UCRI, which are assumed to bind the $2 \mathrm{Fe}-2 \mathrm{~S}$ cluster, and the only one proline, which is unusually arranged between cysteines 3 and 4 .

phaged-isplay library. All of the 89 clones from monoclonal ELISA were positive ( $\mathrm{S} / \mathrm{N}>2.1$ ) (Figure 3 ) and the result was further confirmed by a repeated experiment (Figure 4). This was likely relative to high antigenicity and specificity of SARS-CoV N protein ${ }^{[20-23]}$. Furthermore, the blocking ELISA showed that the synthetic 15-mer peptide could effectively inhibit the binding-specificity of the corresponding phage, containing the native 15-mer peptide insert with the SARS-CoV N protein, and the results (Table 3 ) were in agreement with those of the previous study ${ }^{[24]}$.

Recently, researches on N protein of SARS-CoV have mainly focused on the use of recombinant SARS-CoV N protein ELISA-based antibody tests for the serodiagnosis of SARS-CoV pneumonia and for the study of the seroprevalence of nonpneumonic SARS-CoV infection $^{[25-32]}$. However, Surjit et al. ${ }^{[33]}$ reported that SARS-CoV N protein was capable of inducing apoptosis of COS-1 monkey kidney cells in the absence of growth factors by down-regulating ERK (extracellular-signal-regulated kinase), up-regulating JNK (c-Jun N-terminal kinase) and p38 MAPK (mitogen-activated protein kinase) pathways, and affect their downstream effectors. Moreover, Mizutani et al. ${ }^{[34,35]}$ confirmed that SARS-CoV infection could induce activation of the p38 MAPK signaling pathway and the p38 MAPK inhibitor (Akt) partially could inhibit its cytopathic effect in Vero E6 cells. In fact, the apoptosis induced by SARS-CoV infection was described in other literatures as well ${ }^{[36-40]}$. In addition, previous studies with other coronaviruses, such as Transmissible gastroenteritis virus $(\mathrm{TGEV})^{[41]}$, human coronavirus $(\mathrm{HCoV})$ strain $229 \mathrm{E}^{[19]}$, Mouse hepatitis virus (MHV) ${ }^{[42,43]}$ and Avian infectious bronchitis virus (IBV) ${ }^{[44]}$, indicated that these viruses have evolved strategies to either inhibit or stimulate host cell apoptosis, depending on the particular virus-host interaction. And Eléouët et al. ${ }^{[41]}$ further demonstrated that the TGEV N protein underwent proteolysis in parallel 
with the activation of caspases within the host cell (the human rectal tumor cell line HRT18). Our findings revealed that the proteins with the highest homology to SNA5 binding-specific to SARS-CoV N protein were UCRIs, and in the [2Fe-2S] redox centre of UCRI, there were six residues $[\mathrm{GGW}(\mathrm{Y}) \mathrm{F}(\mathrm{Y}) \mathrm{CP}]$ compatible to the residues (position $2 \rightarrow 7$, GGWFCP7) of the $\mathrm{NH}_{2}$-terminal of the 15-mer peptide. All these suggest that N protein of SARS-CoV functions as an induction factor for apoptosis induced by SARS-CoV infection although such a suggestion has not been further confirmed by any research group.

Ubiquinol-cytochrome c reductase (bc1 complex or complex III) is an enzyme complex of bacterial and mitochondrial oxidative phosphorylation systems ${ }^{[45-47]}$. It catalyzes electron transfer between the two mobile carriers: ubiquinol and cytochrome c, involving a cytochrome b subunit, an iron-sulphur (2Fe-2S) "Rieske" subunit and a cytochrome c1 subunit and leading to the concomitant formation of a proton gradient (linked to ATP synthesis) across the membrane ${ }^{[48-52]}$. Of these, Rieske iron-sulfur protein, which contains a high potential $2 \mathrm{Fe}-2 \mathrm{~S}$ cluster, plays a centre role in the course of cellular energy metabolism ${ }^{[45,53]}$. Based on the possible interaction of SARS-CoV $\mathrm{N}$ protein with UCRI, the

1 Fouchier R A, Kuiken T, Schutten M, et al. Aetiology: Koch's postulates fulfilled for SARS virus. Nature, 2003, 423: 240

2 Ksiazek T G, Erdman D, Goldsmith C S, et al. A novel coronavirus associated with severe acute respiratory syndrome. N Engl J Med, 2003, 348: 1953-1966

3 Peiris J S, Lai S T, Poon L L, et al. Coronavirus as a possible cause of severe acute respiratory syndrome. Lancet, 2003, 361: 1319-1325

4 Drosten C, Gunther S, Preiser W, et al. Identification of a novel coronavirus in patients with severe acute respiratorysyndrome. N Engl J Med, 2003, 348: 1967-1976

5 Berger A, Drosten C, Doerr H W, et al. Severe acute respiratory syndrome (SARS)-paradigm of an emerging viral infection. J Clin Virol, 2004, 29: $13-22$

6 Wu H S, Chiu S C, Tseng T C, et al. Serologic and molecular biologic methods for SARS-associated coronavirus infection. Taiwan Emerg Infect Dis, 2004, 10: 304-310

7 Rota P A, Oberste M S, Monroe S S, et al. Characterization of a novel coronavirus associated with severe acute respiratory syndrome. Science, 2003, 300: 1394-1399

8 Marra M A, Jones S J, Astell C R, et al. The genome sequence of the SARS-associated coronavirus. Science, 2003, 300: 1399-1404

9 Holmes K V, Enjuanes L. VIROLOGY: The SARS coronavirus: A postgenomic era. Science, 2003, 300: 1377-1378

10 Gao H, Peng J P, Deng W, et al. Infection of SARS-CoV on juvenile and adult Brandt's vole Microtus brandtii. Chin Sci Bull, 2005, 50 (12): 1199-1204

11 Zhong N S, Zeng G Q. Our strategies for fighting severe acute respi- possible molecular mechanisms of SARS-CoV N protein in the pathogenesis of SARS were therefore speculated in two levels as follows:

(1) The N protein of SARS-CoV may inhibit electron transfer in the mitochondrial respiratory chain at the levels of complex III, which leads to overstock of cytochrome $\mathrm{c}$ in the mitochondrial respiratory chain and the release of cytochrome $\mathrm{c}$ triggers apoptosis.

(2) The N protein of SARS-CoV may inhibit ATP synthesis in mitochondrial energy metabolizing level, which causes onset of the mitochondrial permeability transition (MPT) and the dissipation of the mitochondrial transmembrane potential, as well as the translocation of cytochrome $\mathrm{c}$ and apoptosis-inducing factor (AIF) from mitochondria to an extra-mitochondrial localization, thereby causing apoptosis.

Currently, efforts are underway to further investigate the phenomenon and mechanism of apoptosis induced by the SARS-CoV N protein, which may be useful for exploring the relation of release of cytochrome $\mathrm{c}$ or AIF and electron transfer or energy metabolization in apoptotic signal transduction pathway mediated by mitochondria, and for resolving the virus pathogenesis with the aim to develop new drugs and vaccines against SARS.

ratory syndrome (SARS). Am J Respir Crit Care Med, 2003, 168: 7-9

12 Holmes K V. SARS-associated coronavirus. N Engl J Med, 2003, 348 : $1948-1951$

13 Holmes K V. SARS coronavirus: A new challenge for prevention and therapy. J Clin Invest, 2003, 111: 1605-1609

14 Wong R S, Wu A, To K F, et al. Haematological manifestations in patients with severe acute respiratory syndrome: Retrospective analysis. BMJ, 2003, 326: 1358-1362

15 O’Donnell R, Tasker R C, Roe M F E. SARS-Understanding the coronavirus: Apoptosis may explain lymphopenia of SARS. BMJ, 2003, 327: 620

16 Tan Y J, Fielding B C, Goh P Y, et al. Over-expression of 7a, a protein specifi-cally encoded by the severe acute respiratory syndrome (SARS)-coronavirus, induces apoptosis via a caspase-dependent pathway. J Virol, 2004, 78: 14043-14047

17 Liu Z X, Yi G H, Qi Y P, et al. Identification of single-chain antibody fragments specific against SARS-associated coronavirus from phage-displayed antibody library. Biochem Biophys Res Commun, 2005, 329(2): 437-444

18 Jeremiah T S, Genevieve L, James A H, et al. Monoclonal antibody-based blocking Enzyme-Linked Immunosorbent Assay for specific detection and titration of Peste-Des-Petits-Ruminants Virus antibody in Caprine and Ovine sera. J Clin Microbiol, 1993, 5: 1075- 1082

19 Collins A R. In vitro detection of apoptosis in monocytes/macrophages infected with human coronavirus. Clin Diagn Lab 
Immunol, 2002, 9(6): 1392-1395

20 Shi Y, Yi Y, Li P, et al. Diagnosis of severe acute respiratory syndrome (SARS) by detection of SARS coronavirus nucleocapsid antibodies in an antigencapturing enzyme-linked immunosorbent assay. $\mathrm{J}$ Clin Microbiol, 2004, 41: 5781-5782

21 Liu G, Hu S, Hu Y, et al. The C-terminal portion of the nucleocapsid protein demonstrates SARS-CoV antigenicity. Genomics Proteomics Bioinformatics, 2003, 1(3): 193-197

22 Guan M, Chen H Y, Foo S Y, et al. Recombinant protein-based enzyme-linked immunosorbent assay and immunochromatographic tests for detection of immunoglobulin $\mathrm{G}$ antibodies to severe acute respiratory syndrome (SARS) coronavirus in SARS patients. Clin Diagn Lab Immunol, 2004, 11: 287-291

$23 \mathrm{Lu}$ J, Zhou B P, Zhou Y S, et al. Molecular cloning and expression of the severe acute respiratory syndrome-associated coronavirus nucleocapsid protein and its clinical application. Chin J Exp Clin Virol (in Chinese), 2005, 19 (1): 64-67

24 Deng L M, Yuan S Z, Chen G Z, et al. A study of serum IGG antibodies to herpes simplex type-1 antigens of gastroduodenal mucosa in peptic ulcer. Acad J SUMS, 1992, 13(2):70-73

25 Woo P C Y, Lau S K P, Wong B H L, et al. Detection of specific antibodies to severe acute respiratory syndrome (SARS) coronavirus nucleocapsid protein for serodiagnosis of SARS coronavirus pneumonia. J Clin Microbiol, 2004, 42: 2306-2309

26 Woo P C Y, Lau S K P, Tsoi H W, et al. Relative rates of non-pneumonic SARS coronavirus infection and SARS coronavirus pneumonia. Lancet, 2004, 363: 841-845

27 Lau S K P, Woo P C Y, Wong B H L, et al. Detection of severe acute respiratory syndrome (SARS) coronavirus nucleocapsid protein in SARS patients by Enzyme-Linked Immunosorbent Assay. J Clin Microbiol, 2004, 42(7): 2884-2889

28 Sun Z F, Meng X J. Antigenic cross-reactivity between the nucleocapsid protein of severe acute respiratory syndrome (SARS) coronavirus and polyclonal antisera of antigenic group I animal coronaviruses: Implication for SARS diagnosis. J Clin Microbiol, 2004, 42(5): $2351-2352$

29 Liu X, Shi Y L, Li P, et al. Profile of antibodies to the nucleocapsid protein of the severe acute respiratory syndrome (SARS)-associated coronavirus in probable SARS patient. Clin Diagn Lab Immunol, 2004, 11(1): $227-228$

$30 \mathrm{He}$ Q, Du Q, Lau S, et al. Characterization of monoclonal antibody against SARS coronavirus nucleocapsid antigen and development of an antigen capture ELISA. J Virol Methods, 2005, 127(1): 46-53

31 Saijo M, Ogino T, Taguchi F, et al. Recombinant nucleocapsid protein-based IgG enzyme-linked immunosorbent assay for the serological diagnosis of SARS. J Virol Methods, 2005, 125(2): 181-186

32 Qiu M, Wang J, Wang H, et al. Use of the $\mathrm{COOH}$ portion of the nucleocapsid protein in an antigen-capturing enzyme-linked immunosorbent assay for specific and sensitive detection of severe acute respiratory syndrome coronavirus. Clin Diagn Lab Immunol., 2005, 12(3): $474-476$

33 Surjit M, Liu B, Jameel S, et al. The SARS coronavirus nucleocapsid protein induces actin reorganization and apoptosis in COS-1 cells in the absence of growth factors. Biochem J, 2004, 383(1): 13-18

34 Mizutani T, Fukushi S, Saijo M, et al. Importance of Akt signaling pathway for apoptosis in SARS-CoV-infected Vero E6 cells. Virology, 2004, 327(2): 169-174

35 Mizutani T, Fukushi S, Saijo M, et al. Phosphorylation of p38 MAPK and its downstream targets in SARS coronavirus-infected cells. Biochem Biophys Res Commun, 2004, 319: 1228-1234

36 Zhang Q L, Ding Y Q, He L, et al. Detection of cell apoptosis in the pathological tissues of patients with SARS and its significance. J First Mil Med Oniv (in Chinese), 2003, 23(8): 770-773

37 Yan H, Xiao G, Zhang J, et al. SARS coronavirus induces apoptosis in Vero E6 cells. J Med Virol, 2004, 73(3): 323-331

38 Ito N, Mossel E C, Narayanan K, et al. Severe acute respiratory syndrome coronavirus 3a protein is a viral structural protein. J Virol, 2005, 79(5): $3182-3186$

39 Jiang Y, Xu J, Zhou C Z, et al. Characterization of cytokine and chemokine profiles of severe acute respiratory syndrome. Am J Respir Crit Care Med, 2005, 10: 1164

40 Curreli F, Friedman-Kien A E, Flore O. Glycyrrhizic acid alters Kaposi sarcoma-associated herpesvirus latency, triggering p53-mediated apoptosis in transformed B lymphocytes. J Clin Invest, 2005, 115: $642-652$

41 Eléouët J F, Slee E A, Saurini F, et al. The viral nucleocapsid protein of transmissible gastroenteritis coronavirus (TGEV) is cleaved by caspase-6 and -7 during TGEV-induced apoptosis. J Virol, 2000, 74(9): 3975-3983

42 Belyavsky M, Belyavskaya E, Levy G A, et al. Coronavirus MHV-3-induced apoptosis in macrophages. Virology, 1998, 250(1): 41-49

43 An S, Chen C J, Yu X, et al. Induction of apoptosis in murine coronavirus-infected cultured cells and demonstration of $\mathrm{E}$ protein as an apoptosis inducer. J Virol, 73(9): 7853-7859

44 Liu C, Xu H Y, Liu D X. Induction of caspase-dependent apoptosis in cultured cells by the avian coronavirus infectious bronchitis virus. $\mathrm{J}$ Virol, 2001, 75(14): 6402-6409

45 Harnisch U, Weiss H, Sebald W. The primary structure of the iron-sulfur subunit of ubiquinol cytochrome $\mathrm{c}$ reductase from Neurospora, determined by cDNA and genes equencing. Eur J Biochem, 1985, 149: 95-99

46 Gabellini N, Sebald W. Nucleotides equence and transcription of the fbc operon from Rhodopseudomon assphaeroides_-Evaluation of the deduced amino acid sequences of the FeS protein, cytochrome b and cytochrome c1. Eur J Biochem, 1986, 154: 569-579

47 Kurowski B, Ludwig B. The genes of the Paracoccus denitrificans bc1 complex-nucleotide sequence and homologies between bacterial and mitochondrial subunits. J Biol Chem, 1987, 262: 13805-13811

48 Nishikimi M, Hosokawa Y, Toda H, et al. The primary structure of human Rieske iron-sulfur protein of mitochondrial cytochrome bc1 complex deduced from cDNA analysis. Biochem Int, 1990, 20: $155-160$

49 Pennacchio L, Bergmann A, Fukushima A, et al. Structure, sequence and location of the UQCRFS1 gene for the human Rieske Fe-S protein. Gene, 1995, 155: 207-211

50 Sarto C, Marocchi A, Sanchez J C, et al. Renal cell carcinoma and normal kidney protein expression. Electrophoresis, 1997, 18: 599-604

51 Strausberg R L, Feingold E A, Grouse L H, et al. Generation and initial analysis of more than 15,000 full-length human and mouse cDNA sequences. Proc Natl Acad Sci USA, 2002, 99: 16899-16903

52 Grimwood J, Gordon L A, Olsen A S, et al. The DNA sequence and biology of human chromosome 19. Nature, 2004, 428: 529-535

53 Madueno F, Napier J A, Cejudo F J, et al. Import and processing of the precursor of the Rieske FeS protein of tobacco chloroplasts. Plant Mol Biol, 1992, 20: 289-299 